\title{
JEREMIAH: PROPHET AND BOOK
}

\section{J. Gordon McConville}

Though it is one of the less celebrated cruces in the critical interpretation of the Old Testament, the Book of Jeremiah (Jer) is an excellent case study in the problems in understanding the meaning of a prophetic book, as well as the relationship between the prophetic figure who lies behind it and the formation of the book itself. Jer is particularly interesting because of its resistance to the establishment of a consensus view of it. The history of its criticism is characterized, on the contrary, by a great divide.

On one side of the divide stand those who, taking their cue ultimately from B. Duhm, ${ }^{1}$ attribute only a relatively small proportion of the book directly to the prophet. The classic formulation of this position was achieved by S. Mowinckel. Building on Duhm's premiss that only the poetic oracles could be authentic to the prophet Jeremiah Mowinckel distinguished two further types of material, namely biographical accounts of the prophet's activities ( $\mathrm{B}$ '), and prosaic sermons (' $\mathrm{C}$ '): the poetic oracles themselves he called (' $A$ '). The sermons were attributed, again in line with Duhm, to a 'Deuteronomic' source.'

The grounds for such a distinction between parts of the material were in part stylistic, as is clear already from Duhm's over-riding criterion of the authenticity of the poetic oracles. The stylistic grounds were not confined to Duhm's axiom, however, but consisted also in the similarity of some of the prose, especially the sermons, to parts of the Deuteronomistic History. Detailed parallels between the two corpora were pointed out by both E. Janssen and E.W. Nicholson. ${ }^{3}$ The belief

\footnotetext{
${ }^{1}$ B. Duhm, Jeremia (Tübingen and Leipzig, Mohr 1901).

${ }^{2} \mathrm{~S}$. Mowinckel, Zur Komposition des Buches Jeremia (Kristiania, Jacob Dybwad 1914); he modified his position somewhat, so as to associate the sermons more closely with Jeremiah in a later work, Prophecy and Tradition: the Prophetic Books in the Light of Study of the Growth and History of the Tradition (Oslo, Jacob Dybwad 1946).

${ }^{3}$ E. Janssen, Juda in der Exilszeit, (Göttingen, Vandenhoeck and Ruprecht 1956);
} 
that the non-poetic material was in some sense 'Deuteronomic', however, was already present in Duhm.

Nor were the grounds for the distinction exclusively stylistic. It was held, in addition, that the prose sections exhibited certain theological differences from the poetic. They were marked in particular by a strongly conditional covenantal theology, lacking the freshness and immediacy of the authentic prophetic warnings of imminent danger, and betraying rather their home in the chastened reflection of the exile and after. ${ }^{4}$ Specific theological contrasts were also pointed out within the book. How, for example, could the prophet of the temple sermon (Jer. 7:1-15), with its strong plea not to put trust in the permanent-seeming externals of religion, finally promise an everlasting covenant, with its own enduring symbols (Jer. 31 : 38-40; 33:14-26) ? 5

Further developments have tended to consider the book as a rather more thorough-going Deuteronomic production, so that even what once seemed to be sure ground in the quest for a historical Jeremiah, namely the authenticity of the poetic oracles, has been rendered insecure. ${ }^{6}$ The emphasis in this tradition of interpreting Jer has thus fallen more and more upon the book, and attached ever less importance to the life and message of the prophet.

On the other side of the divide are those who believe that Jeremiah himself is to be credited with most or all of the material in the book. This approach goes back to the early part of the present century, and counts among its modern advo-

E.W. Nicholson, Preaching to the Exiles (Oxford, Blackwell 1967) 116ff. Nicholson abandoned the distinction between ' $C$ ' and ' $D$ ' material, regarding the prose in general as deriving from the Babylonian exiles' adjustment to their new circumstances.

${ }^{4} \mathrm{Cf}$. the comments on Duhm and Mowinckel on this topic in L. Stulman, The Prose Sermons of the Book of Jeremiah (Atlanta, Georgia, Scholars Press 1986) 12.

${ }^{5}$ On the theology of New Covenant (Jer. 31:31-4) as a post-Deuteronomistic leap of hope, see R.P. Carroll, Jeremiah (London, SCM 1986 ) 614; cf. ibid., 636-9, for the view that 33:14-26 are a further supplement to the cycle in chs 31-2.

'The source of this trend is J.P. Hyatt, 'The Deuteronomic Edition of Jeremiah', Vanderbildt Studies in the Humanities 1 (1951) 71-95. See also W. Thiel, Die Deuteronomistische Redaktion von Jeremia 1-25 (Wageningen, Neukirchener Verlag 1973). 
cates J. Bright, H. Weippert and W.L. Holladay. ${ }^{7}$ These have in common the belief that the book, in its admitted diversity, can yet be explained within the context of the long and varied ministry of the prophet, who is thus seen as the interpreter of God to Israel in a time when the issues before the people changed swiftly and dramatically. The different styles may correspond to different settings. ${ }^{8}$ They may, indeed, not be so very disparate as they are sometimes believed to be. ${ }^{9}$ Furthermore, the similarity between the Jer prose and that of the Deuteronomistic History has been exaggerated at the expense of the similarities of thought and expression of the various parts of Jeremiah. ${ }^{10}$ Considerations of style and expression apart, indeed, important differences of content stand against the too ready classification of the book, either in part or as a whole, as Deuteronomic. For example, while the Reform of Josiah occupies a prominent and climactic position in Kings (2 $\mathrm{Kg}$. 22f.), that Reform hardly figures in Jeremiah's preaching. Josiah himself is applauded, admittedly, for his faithfulness (Jer. 22:15f.), yet only in passing, as an exception to the otherwise highly pessimistic picture of the kings of Judah in the same chapter. Correspondingly, Jeremiah is not even mentioned in Kings, a curious omission in an account of the last days of Judah.

A further striking difference concerns the topic of hope

\footnotetext{
${ }^{7}$ An early advocate of the authenticity of the whole book was Th. Robinson, 'Baruch's Roll', ZAW 42 (1924) 209-21. More recently: J. Bright, 'The Date of the Prose Sermons of Jeremiah', JBL 70 (1951) 15-35; Jeremiah (New York, Doubleday 1965); H. Weippert, Die Prosareden des Buches Jeremia (Berlin, de Gruyter 1973); W.L. Holladay, Jeremiah 1, 2 (Philadelphia, Fortress 1986, 1989)_the fruit of a published oeuvre spanning many years.

${ }^{8}$ Note in this connection Holladay's theory of septennial readings of Deuteronomy, based on the command in Dt. 31:9-13. Jeremiah's prose he then takes to be a counter-proclamation, in the same style; op. cit., 2 27. The thesis of J.W. Miller, Das Verhältnis Jeremias und Hesekiels Sprachlich und Theologisch Untersucht (Assen, van Gorcum 1955) has elements in common with Holladay; see $32 \mathrm{f}$.

${ }^{9} \mathrm{~J} . \mathrm{L}$. Kugel has shown that the familiar distinction between prose and poetry is not hard and fast, but rather imports categories which are to some extent misleading. He also alerts the reader to the false impressions which can be given by the versification of parts of the biblical text, in both Hebrew and English Bibles; The Idea of Biblical Poetry (New Haven, Yale University Press 1981), especially 76ff., where he illustrates the point in relation to Jer. 30:6-11. ${ }^{10}$ This is the thesis of Bright and Weippert; see note 7.
} 
for the future, presumably all-important to the Babylonian exiles. Kings contains no more explicit statement of this than Solomon's great prayer at the dedication of the temple. In 1 Kings 8:46-53, Solomon anticipates the exile, and prays that, should the exiles repent, they might find compassion in the sight of their enemies; he stops short of praying for restoration to the land. This puts his prayer in interesting contrast to the expression of hope for just such a restoration in Deuteronomy $30: 1-3$. When the Books of Kings end, therefore, with the Jews in exile, it has little within its own thought which can hold out hope of a return. In this respect, Jer, especially in the socalled Book of Consolation, goes beyond Kings, and stands closer to Deuteronomy. ${ }^{11}$ However these differences are to be explained, it is at least true to say that the two great works have chosen to represent both the demise of Judah and the prospect in exile somewhat differently. It is justifiable, therefore, to speak of a specifically Jeremianic understanding of God's purpose in the period, which is not simply 'Deuteronomic'.

I have thus sketched two different approaches to Jeremiah. It will probably be clear from the discussion that I think that a 'Deuteronomic' understanding of the book does too little justice to its individuality. The emphasis on Jer as 'book', particularly in recent discussion, minimizes the role of Jeremiah in its production without adequate justification for doing so. The point may be illustrated by reference to the work of McKane and Carroll.

\section{'Book' Interpretations}

Carroll's treatment of the topic of repentance in Jeremiah 3 illustrates his general approach to the book. The topic is introduced in 3:1-5. This oracle is based upon the law of divorce in Deuteronomy 24:1-4. As a man who divorces his wife may under no circumstances re-marry her, so, it is implied, Yahweh

\footnotetext{
${ }^{11}$ I have elaborated this point in two other articles. In Narrative and Meaning in the Books of Kings', Bib 70 (1989) 31-49, I have tried to show the logic of the Books of Kings, which finish, despite the glories of Josiah, on a note of uncertainty about the future, waiting for God to act in whatever way he will. In ' 1 Kings viii 46-53 and the Deuteronomic Hope', VT forthcoming, I have argued that the prayer of Solomon deliberately stops short of expressing the hope found in Dt. 30:1-3, though it knows the passage.
} 
cannot 'return' to his people once he has rejected them, 3:1. In the same breath, scorn is poured on the idea of Israel 'returning' to him with any sincerity. The 'returning' theme is continued in verses 6-11. Carroll's interpretation (like McKane's) depends on the premiss that verses 6-11 misinterpret verses 1-5. In Carroll's view, that passage, in common with the discourse that begins in chapter 2, bears upon Judah alone. Even where the term 'Israel' appears in chapter 2, it refers in reality to Judah. Therefore, verses 6-11 labour under the false impression that verses 1-5 referred originally to the northern kingdom, and thus develop the comparison between the two kingdoms on a false premiss. 12

This interpretation of 'Israel' in chapter 2 and in 3:1-5 is fragile. Chapter 2 clearly reviews Israel's whole history, both of covenant and apostasy, as its evocation of the wilderness period shows, 2:2f. Its allusions to 'Assyria', furthermore, make most sense if they are recalling the actual experience of the northern kingdom in relation to that Empire. The force of verses 18 and 36 may indeed be that one Empire is much like another as an object of trust. Nevertheless, verse 36 opposes a past experience to a still future one, and has its background in the historical end of Israel (the northern kingdom) at Assyria's hands. (Incidentally, the future tense adopted by some EVV at 2:26 is gratuitous; it should be translated either with a past or a present).

In reality, therefore, Jeremiah 2:1-3:5 really does mean 'Israel' when it says it. It is true that that section does not overtly oppose or compare the two kingdoms. Nevertheless, its meaning is that contemporary Judah is in grave danger because of a present apostasy which is in organic continuity with the apostatizing tendency exhibited in Israel's history broadly understood. It follows that 3:6-11 is a legitimate development of the ideas in that section. ${ }^{13}$

As important as the particular argument of Carroll's on this issue, however, is the method which lies behind it. His

\footnotetext{
${ }^{12}$ Carroll, op. cit., 145f.; of. W. McKane, Jeremiah I (Edinburgh, T. \& T. Clark 1986) 67; idem., 'Poetry and Prose in the Book of Jeremiah with special reference to Jer. iii 6-11 and xii 14-17', SVT 25 (1980) $229 \mathrm{ff}$.

${ }^{13}$ For a fuller treatment of this point see my forthcoming book, Judgment and Promise: the Message of Jeremiah, ch. 1.
} 
interpretation of the repentance topic is in line with his belief that the book has reached its present form as the result of a complex process over a long period, reflecting the experience of different groups in a variety of specific circumstances. In the view of Carroll (and again McKane) the theologizing about repentance here, and the habit of contrasting Judah unfavourably with the former northern kingdom, is an exilic or post-exilic pre-occupation, cf. Ezekiel 16:51f. Its real context is the rivalry between the group that has been through exile in Babylon and that which has not. This rivalry is reflected in the vision of Jeremiah in chapter 24, and in the Book of Ezra. It is a key topos in Carroll's understanding of the whole book. By a curious twist of Carroll's theory, 'Judah' in 3:6-11 must mean the Palestinian group that had not seen Babylon, while 'Israel', the less guilty party, stands for the returning group. ${ }^{14}$

There is some effort of the imagination in all of this. The suggested semiology of the passage is without analogy, and offends against the simplest reading of the text, namely that at some point in his preaching to Judah, Jeremiah compared that people unfavourably with their long lost cousins in the northwhose fate should serve as a warning to them. In fact, Carroll's broader view of the book has produced his angular exegesis. Here, as passim in both his commentary and McKane's, passages are explained against a variety of proposed backgrounds of which we have little in the way of real knowledge.

It is thus assumed that Jeremiah did at some stage in his ministry preach repentance to his contemporaries. The point must be conceded immediately if it is allowed (though not all do) that the temple-sermon of 7:1-15 is authentic to the prophet. However, the issue is more complicated when we ask the question in relation to the passage just discussed. It is important to pursue the point for the following reason. If on the one hand arguments which aim to put distance between the book and the prophet do not always rest on firm evidence (as I think we have seen), there may be an opposite danger, in trying to secure the book for the prophet, of under-estimating the extent to which it is indeed a 'book', and as such a piece of reflective theology.

${ }^{14}$ Carroll, ibid. 
My point about the difficulty of unearthing the repentance preaching of Jeremiah that underlies 3:1-4:4 is that the text which we have seems to bear the marks of a digested reflection on that preaching. This consists in the pervasive sense in the chapter that the people who are called to repent cannot do so. Calls to repent come at 3:12, 14, 22; 4:1. Their most interesting characteristic is the play on the verb שי 'return', 'repent'. The command שִּ (v. 12) is followed immediately by the epithet have a strong tendency to 'turn', indeed, but to turn away from God rather than to him. The thought is most fully developed in 3:22, where the final word on the subject is God's statement: 'I

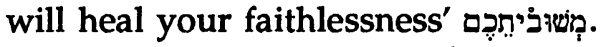

The intervention of God in this way anticipates the theology of the New Covenant, in the sense that there also the failure of Judah to respond to the call to repent is met by a new approach on God's part to the problem of continuing in covenant with her (cf. 24:7; 31:33; 32:39f.; and further below). This means that Jeremiah 3:1-4:4 participates in an important way in the final theological shaping of the whole book. Though it testifies to an actual preaching of repentance on Jeremiah's part (a testimony supported by Jeremiah 7:1-15), it is not an undigested reportage of ipsissima verba; rather, it incorporates the whole trajectory of thinking about repentance in the book. It is a theology of repentance, a reflection on what happens when the covenant people is found unwilling, or perhaps unable, to turn to God definitively.

With these observations, I hope to have illustrated the first of my main contentions. I have said above that many lose sight, gratuitously in my view, of the prophet who lies behind the message. There is an obverse of this, however, namely that those who seek the man behind the book may be diverted by an overly 'biographical' method from doing justice to the book as a 'book', that is, as a sustained theological reflection. The two quests, for the man and for the book, are not, in my view, inimical to each other. We are obliged, however, if we would undertake both, to think carefully about the nature of the relationship between the two. 


\section{'Prophet' Interpretations}

Recent studies of Jeremiah have indeed produced significant attempts to understand the relationship between the prophet and his book on the basic premiss that he was responsible for all or most of it. These studies go beyond the major recent attempts (of Bright and Weippert) simply to establish the likely authenticity of the prose as well as the poetry, to confront the question how the different kinds of theological articulation of Judah's position before Yahweh may be understood together.

It may be worth elaborating the point (made earlier) that such differences do exist side by side in Jer. Jeremiah's 'temple-sermon', for example (7:1-15, and more briefly in 26:26), seems to be a straightforward record of a preaching on the basis of covenantal conditions, which aims to produce repentance on the hearers' part. On the other hand, there are unqualified pictures of coming doom, such as 4:5-8, reinforced by Jeremiah's own anguished and vivid realization of the horrors ahead (Jer. 4:19-21). These, as we shall see, have been variously read either as servant of the call to repent or as a separate stage in Jeremiah's preaching. A further set of passages does make explicit, however, that God's way forward for Judah is through exile: a time for repentance is past. One indicator of this is the repeated prohibition of intercession laid upon the prophet $(7: 16 ; 11: 14 ;$ cf. 15:1). And the clearest representation of the point is in the vision of the two baskets of figs (ch. 24), in which the good figs are those who go into exile, and the bad are those who refuse. The former are those who have acquiesced in God's purposes, and who therefore have a future with him; the latter he has rejected. Much of Jeremiah's later ministry seems to have been devoted to the proposition that the duty of king and people was to submit to the Babylonian yoke (21:9; 27:8-11), understandably provoking passionate hostility, and the suspicion of treachery (37:11-15). The exile was the only means by which a future might be secured for the covenant people (29:10-14). Repentance preaching thus gives way to another kind of appeal. The movement from repentance preaching to an acknowledgement of its failure, and of the consequent need for God to act in some other way, was evident in the treatment of the repentance theme itself in 3:1-4:4. The same 
movement may also be found in the book as a whole. There is evidently a chronological dimension to this change. The preaching of repentance obviously only makes sense before the beginning of Nebuchadnezzar's ravages of Judah (597); correspondingly, the preaching of exile as a part of God's determined plan is firmly associated in the book with the reign of Zedekiah, i.e. between the two main attacks on Judah, and prior to the fall of Jerusalem (see ch. 24). The recognition of this chronological dimension, however, does not immediately solve the problem of the composition of the book.

One attempt to account for the change is that of T. M. Raitt. He traces a development from the early repentance preaching through a time when Jeremiah preached inevitable annihilation, to a final stage when he once again preached salvation, now on the basis of New Covenant theology (31:3134). The development, therefore, follows a clear chronological line. Indeed, Raitt says that his 'suggestion of developmental sequence in Jeremiah's and Ezekiel's message is one of the most basic hypotheses offered in this book' ${ }^{15}$ That hypothesis is supported by a form-critical argument, according to which the various stages of the prophecy are conveyed by forms which are suitable to the particular message. Thus, in the second stage, when Jeremiah is pronouncing complete annihilation and the end of the covenant, the chosen form is the Oracle of Judgment. The ideological framework of the Oracle of Judgement is the Mosaic covenant. In the hands of Jeremiah, however, the covenantal principle of justice comes to be more fundamental than that of election; '. . .strictly covenantal concerns are largely superseded, and prophetic theology is stretched to a breaking-point ${ }^{\prime}{ }^{16}$ The Oracle of Judgement, therefore, adopts a distinct interpretation of the fate of Judah both from the idea of exile as a chastisement (as in Lev. 26:44, which Raitt sees as deliberately opposing Jeremiah), or, to vary the thought slightly, from 'remnant-theology' ${ }^{17}$ It is important to be clear about Raitt's position here. He is not simply saying that

${ }^{15}$ T.M. Raitt, A Theology of Exile: Judgment and Deliverance in Jeremiah and Ezekiel (Philadelphia, Fortress 1977) 36.

16Ibid., 31.

${ }^{17}$ Ibid., 26, 32. 
Jeremiah has not yet developed a remnant-theology when he preaches judgment. Such theology, after all, already exists within the prophetic tradition (as in Hosea). Rather, he believes that Jeremiah's Oracle of Judgement actively repudiates such theology. His subsequent adoption of it, therefore, is by way of a volte-face.

Raitt has made important observations on the nature of form-criticism, in which he rightly criticizes much use of it as too rigid. ${ }^{18} \mathrm{He}$ has also correctly observed the element of theodicy in Jeremiah's preaching of judgment. ${ }^{19}$ Nevertheless, his differentiation of the three 'stages' of Jeremiah's prophecy is itself too rigid. The idea that the Oracle of Judgement proclaims annihilation in an unqualified way, and that it is a consciously distinct route from other messages in the book, is open to question. On the one hand, it is hard to think that Jeremiah was not actually aiming for repentance when he uttered an exhortation such as 4:8-the girding with sackcloth, lamenting and wailing being signs of penitence. On the other, the Oracle of Judgement can contain a hint like 9:7 that the judgment will have a purgative intention. Raitt's analysis, therefore, has its own rigidity, and has not, I believe, finally accounted for the relationship of the various parts of Jeremiah's message to each other.

J. Unterman has in common with Raitt a belief that a development in Jeremiah's thought can be traced in distinct stages. His approach, however, is rather more theologically orientated, beginning from the question whether Jeremiah regarded repentance as a prerequisite of redemption. (Repentance is defined as a decisive turning towards God; redemption is the act of God's mercy, restoring the blessings of the covenant). ${ }^{20}$ Unterman's study of the theme turns on the belief that Jeremiah's thought underwent a transition in relation to it. Unlike Raitt, he does not imagine a time when Jeremiah abandoned a belief in salvation at all; rather, the preaching of

\footnotetext{
${ }^{18}$ T.M. Raitt, op. cit., $150 \mathrm{ff}$. He makes the telling point that form-criticism, as usually conceived, can hardly deal with any 'new' situation. Notice also his perceptive critique of Begrich, ad loc.

${ }^{9}$ Ibid., $88 \mathrm{ff}$.
}

${ }^{20} \mathrm{~J}$. Unterman, From Repentance to Redemption (Sheffield, JSOT 1987) 11. 
judgment had repentance and restoration as its goal. ${ }^{21}$ Salvation, therefore, is always in view. The question is only how it is attained. Unterman is right, I believe, in his basic understanding of 2:4-4:4 as Jeremiah's own composition, reflecting his theological reasoning about the topic. ${ }^{22}$ Nevertheless, his treatment also encounters problems when it attempts to trace a process in the prophet's thought along a time-line. Unterman's thesis is that Jeremiah's earliest preaching shows a belief that redemption is dependent on repentance (as in 3:12f.), that in a transitional phase he saw the need for repentance receding in favour of a redemptive act of God (e.g. 24:4-7), and that finally he abandoned the former altogether (as in 31:27-34).

Unterman's attempt to account for the data in Jeremiah is commendable because of its recognition that they are the deposit of the book's handling of a difficult theological topic. In pursuit of it, he makes numerous perceptive criticisms of literary-critical manoeuvres which unnecessarily force texts apart. However, he himself introduces polarities into the theological discussion which, in their own way, are just as insecure.

The problem lies in his handling both of the texts and the concepts. Crucial to his argument is the belief that theologies of repentance and redemption can and sometimes do lie at opposite ends of a spectrum. Thus the Deuteronomist is strongly influenced by the former. For this reason Deuteronomy 30:1-10 is decisively different from Jeremiah $24: 4-7$, for while both anticipate redemption, the passage in Deuteronomy lays down repentance as a condition, but in Jeremiah 24 it is muted, and in Unterman's view clearly receding in favour of an emphasis on God's mercy. ${ }^{23}$ I have already said that on the subject of hope for the future, Jer lies close to Deuteronomy 30:1-10.24 And in fact, Unterman's contrast cannot be maintained, for two reasons. First, it fails to realize to what extent Deuteronomy itself contains reflection on the relationship between repentance and redemption. The point may be illustrated by a comparison of

${ }^{21} \mathrm{~J}$. Unterman, op. cit., 37.

22Ibid., 36-8.

23Ibid., 64-7.

${ }^{24}$ See n. 11. 
Deuteronomy 10:16 with Deuteronomy 30:6. While the metaphor of circumcision of the heart appears in both, there is an unmistakable shift from the former to the latter, in which God himself effects the circumcision. This shift evidently belongs within the reflection that characterizes the discourse of Deuteronomy broadly conceived. Deuteronomy, therefore, is by no means propounding a theology of repentance that is opposed to one of redemption. Rather it is precisely recognizing the complexity of that theological topic.

The second objection to finding a significant contrast between the two passages lies in the superficial grounds found for it in the texts. Unterman regards repentance as secondary in importance in Jeremiah 24:4-7 because it appears only in verse $7 \mathrm{~b}$, at the end of the passage. This positioning, however, hardly demonstrates negligibility; indeed the reverse could be argued equally plausibly. The idea that the repentance demand is 'receding' here is actually quite subjective.

In fact, Unterman's specific argument about the relation between repentance and redemption finally founders because of the essential improbability of the view that they are, or are potentially, rival theologies. That view leads him into a number of fragile interpretations of texts. This is best illustrated by his treatment of some which he finds difficult to place. On 30:5-17, for example, he finds Jeremiah vacillating between the call to repent and the promise of redemption, and even wonders whether he might for a time have held two different views simultaneously. ${ }^{25}$ Such a conclusion should have suggested that the trail was false.

There is in fact a flaw in the procedure, adopted by Unterman, by which texts are isolated from each other and from larger contexts and taken, by virtue of their particular form of expression, to represent points on a spectrum of views about a topic. (Thus texts which make promises about the future but which omit the terminology of repentance are taken to have rejected the idea). ${ }^{26}$ There is no account either, on this view, of the book as a whole, in which the various texts discussed are held to be from Jeremiah, yet according to which it

25J. Unterman, op. cit., 138.

${ }^{26}$ Ibid., 89ff. 
contains ideas which, ex hypothesi, he rejected. ${ }^{27}$

\section{A Third Way}

In response to both Raitt and Unterman it may be urged that the book of Jer contains rather sophisticated reflection on the relationship between repentance and redemption, and that the various texts on the topic have their place in it. Indeed, I believe that what was said above about the nature of the composition in Jeremiah 3:1-4:4 applies to the whole book. That is, there is a sustained treatment in the book of the problem of Israel/Judah's failure to respond to God in the way in which the covenant required. The book in its final form knows the outcome of the preaching of Jeremiah, and therefore the record of his ministry is not merely such, but also a casting of the issues in the context of a discussion $a$ posteriori.

The thesis can be elaborated only sketchily here (its character having been adumbrated by the treatment of 3:1-4:4 above). ${ }^{28}$ In trying to understand the development, it is clear that one must recognize a chronological aspect to it. However, it is, in a sense, merely part of the staging of the discussion. The issue throughout is how there may be a future for the people of God in view of their refusal to meet the covenant demands. The story opens (though its stages do not correspond neatly with parts of the book, or not uniformly so) with echoes of repentance preaching (as in 7:1-15) side by side with pictures of a people that cannot repent (e.g. 3:1-4:4. The topic is developed more broadly throughout chs 2-20). The line of development continues with the recognition that judgment must therefore ensue, as a means of the relationship continuing (21-24). The survival of the covenant depends wholly on the gracious initiative of God, which is conceived as something quite new

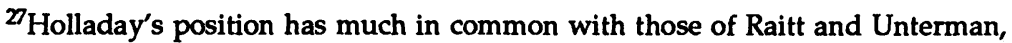
especially the former. His account of transitions in Jeremiah's thought is similar to Raitt's, though he perhaps draws less firm distinctions between the different stages; see op. cit., 2 78-80. Holladay's theory about the development of Jeremiah as a succession of scrolls may give a fixity to the various parts of the book which would enable him to account for the coexistence of different answers to the question about Judah's future in its final form. However, this in turn seems to prohibit interpretation of them in conscious relation to each other as Jeremiah's specific contribution to the topic.

${ }^{28}$ Its full articulation is the subject of my Judgment and Promise (op. cit.).
} 
(31:31-34), but which does not relinquish the basic understanding of covenant as one of mutual commitment in which the obedience of the human partner is indispensable. This is the context of 24:7, 31:33 and, most explicitly, of 32:39f. The idea of God enabling the obedience is precisely Jeremiah's answer to the basic problem. It also stands as the book's answer to the question how such uncompromising criticism of the temple worship as is found in 7:1-15 can be followed by a passage like 33:14-26, which affirms so categorically the permanence of the very institutions which Jeremiah once excoriated. The transformation of Jeremiah from prophet of judgment to prophet of salvation, incidentally, is not undertaken lightly. It is very carefully portrayed and explained in chapter $28 \mathrm{f}$., where he confronts those salvation-prophets who do not recognize the need of a purging of the people in exile. The whole dramatization of the prophet's life, indeed, may be said to aim to show that this transformation was, as it were, through fire. It is the theology of New Covenant, together with the portrayal of Jeremiah's experience in himself of the judgment of God, which enables the transition to hope.

The issue of the irreversible requirement of obedience in the covenant people does not go away, however, after the Book of Consolation (i.e. Jer. 30-33). Rather, it continues to be aired in the persistent refusal of the remnant in Judah following 586 BC to hear God's word through the prophet (chs. 40-4). In this account, the judgment on those who would refuse the purging experience of Babylon (in terms of 24:1-7), though it seems determined in that vision, is shown also to be chosen and merited. Finally, the Oracles against the Nations (Jer. 46-51) reverse early warnings addressed to Judah. Babylon, the destroying 'foe from the north', falls in turn to another of the same (50:3). In the logic of Jer, its fate follows appropriately on God's use of it as a scourge of his people. It had its time, just as there was a time of purging for Judah, but falls in the end, a victim of its own concupiscence, and helpless witness of God's vindication of its former prey. The position of the Oracles against the Nations in MT (as opposed to their position after 25:13 in LXX) is well fitted to their function there, providing a suitable climax to the book.

The topic of hope for the future, therefore, understood 
as the question about the survival of covenant and covenant people, is the object of sustained reflection in Jer. The chronological development is subsidiary to a theological and literary one. This is why it is difficult to recover a chronology of the prophet's life; it is not the subject of the book.

\section{Conclusions}

With these observations, we return to the question posed at the outset, namely that of the relationship between prophet and book. By means of a consideration of the topic of repentance and redemption we considered the cases first, for the treatment of Jeremiah primarily as 'book', to the extent that its connection with the prophet became slight or negligible, and secondly for accounts which maximized the involvement of the man in the literary work which we now have. In the first case, we found the most extreme 'book' approaches were not supported by firm evidence in their minimizing of Jeremiah's influence. In the second, however, we found that interpretations which took the prophet's life as the true context of the words attributed to him were insufficiently sensitive to the 'book' aspect of his literary deposit. In charting the developments of Jeremiah's thoughtwhich they did more or less plausibly-they did not account satisfactorily for the coexistence of its various stages in the final product.

The foregoing does not intend to adopt the former course outlined. The programme of the book cannot, I believe, be simply assimilated to the anonymous 'Deuteronomistic' endeavours of the exilic period, as I have maintained above. I intend rather to show two things. The first is that the book may be derived quite genuinely from Jeremiah. This proposition depends not only on what I see as the failure of others to provide convincing alternative hypotheses for the setting of the book, but also on a view of the nature of the Israelite prophetic tradition, within which, I think, the contents of Jer can reasonably be understood. For example, the repentance trajectory which we discovered in Jer can also be found in Hosea. This, it may be replied, raises a difficult question about the nature of the dependence of Jeremiah on the earlier source, when one is proposing an actual progression in the thought of the later prophet. Nevertheless, the authenticity of the substance of Hosea cur- 
rently enjoys a rather secure footing in OT scholarship. Furthermore, points of contact between Jer and earlier prophetic books are numerous and broad in their range. ${ }^{29}$

My second intention, however, is to show that the book does not derive from the prophet in a simple way, as if it were a mere collection of logia which, for all their authenticity, made little sense as a whole thing. The words are, I suggest, those of Jeremiah-ben-Hilkiah, a prophet of Judah in the broad Israelite prophetic tradition. They are transmitted to us, however, by means of his own mature reflection on them, in the light of his experience both of God and of God's dealings with his people in history. Jer as a book, therefore, forms a part of the OT's evaluation of the experience of exile. This, then, is to maintain a distinction in principle, between the life of the man and the meaning of his book, though the two are interwoven. Only an approach of this sort can, I think, both acknowledge the variety of thought in the book, and find an explanation for it that satisfactorily maintains its coherence.

${ }^{29}$ See Holladay, op. cit., 2 44ff.; McConville, op. cit., ch., 8. 